\title{
Article \\ Higher Level of Sports Activities Participation during Five-Year Survival Is Associated with Better Quality of Life among Chinese Breast Cancer Survivors
}

\author{
Yuan-Yuan Lei ${ }^{1}$, Suzanne C. Ho ${ }^{2}$, Ka-Li Cheung ${ }^{1}$, Victoria A. Yeo ${ }^{1}$, Roselle Lee ${ }^{1}$, Carol Kwok ${ }^{3}$, Ashley Cheng ${ }^{3}$, \\ Frankie K. F. Mo ${ }^{1,4}$ and Winnie Yeo ${ }^{1,4, * \mathbb{D}}$
}

1 Department of Clinical Oncology, Prince of Wales Hospital, The Chinese University of Hong Kong, New Territories, Hong Kong, China; yuanyuanlei@cuhk.edu.hk (Y.-Y.L.); carleycheung@cuhk.edu.hk (K.L.C.); yeob2003@gmail.com (V.A.Y.); roselle_lee@hotmail.com (R.L.); frankie@clo.cuhk.edu.hk (F.K.F.M.)

2 Division of Epidemiology, The Jockey Club School of Public Health and Primary Care, The Chinese University of Hong Kong, New Territories, Hong Kong, China; suzanneho@cuhk.edu.hk

3 Department of Clinical Oncology, Princess Margaret Hospital, Hong Kong, China; kwockch@hl.org.nk (C.K.); ackcheng@ha.org.hk (A.C.)

4 State Key Laboratory in Oncology in South China, Faculty of Medicine, Hong Kong Cancer Institute, The Chinese University of Hong Kong, New Territories, Hong Kong, China

* Correspondence: winnieyeo@cuhk.edu.hk; Tel.: +852-26322118

Citation: Lei, Y.-Y.; Ho, S.C.; Cheung, K.-L.; Yeo, V.A.; Lee, R.; Kwok, C.; Cheng, A.; Mo, F.K.F.; Yeo, W. Higher Level of Sports Activities

Participation during Five-Year Survival Is Associated with Better Quality of Life among Chinese Breast Cancer Survivors. Cancers 2021, 13, 6056. https://doi.org/10.3390/ cancers13236056

Academic Editors: Luisa SoaresMiranda and Eduardo Bruera

Received: 6 October 2021

Accepted: 30 November 2021

Published: 1 December 2021

Publisher's Note: MDPI stays neutral with regard to jurisdictional claims in published maps and institutional affiliations.

Copyright: (c) 2021 by the authors. Licensee MDPI, Basel, Switzerland. This article is an open access article distributed under the terms and conditions of the Creative Commons Attribution (CC BY) license (https:// creativecommons.org/licenses/by/ $4.0 /)$.
Simple Summary: Engaging in sports activities is strongly encouraged for cancer survivors. We aim to investigate the association between the level of sports activities participation post-diagnosis and quality of life (QoL) among Chinese women with early-stage breast cancer during the first five years of survival. Notably, we confirm in this work that regular participation in sports activities following cancer diagnosis may have a positive effect on patients' QoL.

Abstract: Evidence about the association between the level of sports activities participation postdiagnosis and quality of life (QoL) among Chinese women with early-stage breast cancer is limited. A validated modified Chinese Baecke questionnaire was used to prospectively measure sports activities among a breast cancer cohort at four time-points: baseline and 18, 36, and 60 months after diagnosis (sports activities during the previous 12 months before each interview); QoL was measured at the same time. In total, 1289, 1125, and 1116 patients were included in the analyses at 18-, 36- and 60-month follow-up, respectively. The percentages of patients who belonged to no ( 0 metabolic equivalent of task (MET)-hours per week), low-level ( $<10$ MET-hours/week), and high-level ( $\geq 10$ MET-hours/week) sports activities group were $20.7 \%, 45.5 \%$, and $33.8 \%$ at 18 -month follow-up, respectively; the corresponding figures at 36 and 60 months differed slightly. Using data from the three follow-ups, generalized estimating equation (GEE) analyses showed that higher levels of sports activities participation were associated with better QoL in several items as well as fewer symptoms. The present findings in Chinese women with breast cancer provide important evidence on the beneficial effect of regular participation in sports activities following cancer diagnosis on patients' QoL.

Keywords: breast cancer; sports activity; quality of life; the first five years of survival; Chinese women

\section{Introduction}

Survival analysis based on cancer registry data indicates that the incidence of breast cancer has increased steadily; on the other hand, in recent decades in Hong Kong, the mortality rate has only increased slightly over the same period [1]. These trends have resulted in a rising number of women who will live longer as breast cancer survivors. According to the American Cancer Society (ACS), a cancer survivor is defined as any individual who has been diagnosed with cancer [2]. As the survival rate quantitatively increases, the 
improvement of quality of life (QoL) becomes a critical long-term management issue for breast cancer survivors [3,4]. Previous studies have reported that both newly diagnosed breast cancer patients and long-term breast cancer survivors have worse QoL than healthy female controls $[5,6]$. As such, identifying effective strategies, especially by the adoption of healthy lifestyles, to improve QoL has been explored among breast cancer survivors.

Among modifiable lifestyle habits after a breast cancer diagnosis, participation in sports activities is one of the factors that has been associated with a reduced risk of mortality [7-9] as well as enhanced QoL [10-13]. A large body of short-term, structured exercise interventional programs has been completed by breast cancer patients. A few recently published meta-analyses have summarized the evidence and reported positive associations between exercise and QoL [14-16]. The above-mentioned interventional studies were mainly based on Western populations, while reports on Asian populations remain scarce. Another interesting finding was that completely or partially supervised training programs appeared to achieve greater improvement in QoL than those predominantly unsupervised or home-based ones [17]. On the other hand, observational studies evaluate patients' self-motivated participation in sports activities and are reflective of patients' daily habits. Up to now, several observational studies have been reported, including cohort studies and cross-sectional studies, suggesting an association between regular sports activities engagement and better QoL [18-29]. However, among these observational studies, only one cohort study has been reported in Chinese women with breast cancer [20].

Although numerous studies have reported positive associations between exercise and QoL among breast survivors, the underlying mechanisms remain unclear. The results from a lifestyle modification program, including adopting a healthy diet pattern and doing exercises, suggested that lifestyle factors may impact QoL positively, possibly through weight loss [30]. It is well recognized that Asian women have a lower body mass index (BMI) than Western women [31]. In addition, our previous study showed that less than $10 \%$ of Chinese women with breast cancer were obese, according to the BMI classification of the World Health Organization (WHO) [32]. Taken together, these data suggest that the beneficial impact of exercise on QoL may differ between Western and Chinese women. Hence, studies that specifically address this aspect in Asian patients are still essential.

The present study aims to evaluate the association between the level of sports activities and QoL among Chinese women with early-stage breast cancer during the first five years of their survival. It hypothesizes that a higher level of sports activities is associated with better QoL.

\section{Materials and Methods}

\subsection{Patients}

The Hong Kong NTEC-KWC Breast Cancer Survival Study (HKNKBCSS) was a prospective study among Chinese women with early-stage breast cancer that was initiated in 2011. It aimed to evaluate the associations between lifestyle factors, especially soy isoflavones intake, and the outcomes of breast cancer [33-37]. The study was approved by the Joint CUHK-NTEC Clinical Research Ethics Committee and the KWC Research Ethics Committee of the Chinese University of Hong Kong and the Hong Kong Hospital Authority.

The enrollment of this cohort took place between January 2011 and February 2014 in two regional cancer centers in Hong Kong. Consecutive breast cancer patients who attended outpatient clinics were identified for the study; eligible patients were invited to participate in the study. Inclusion criteria included Chinese females who were of any age, with histologically confirmed breast cancer at American Joint Committee on Cancer (AJCC) stage 0-III [38], mentally stable, able to read Chinese, and who did not have a prior history of breast or other cancers. These patients should have a diagnosis of breast cancer of no more than 12 months from study entry. Written informed consent was obtained from each individual prior to study entry. Each participant was interviewed at four timepoints according to the study protocol: baseline at study entry, and 18, 36, and 60 months post-diagnosis. 


\subsection{Data Collection of Socio-Demographic Characteristics and Clinical Information}

Each participant had a face-to-face assessment by trained interviewers at baseline and during the three follow-ups. During the assessment, patients' socio-demographic information was collected. The clinical records were retrieved for details of breast tumor characteristics and anti-cancer treatment. In addition, disease recurrence and survival status were updated periodically by reviewing medical records during the follow-ups or by asking patients or family contacts through face-to-face interviews or telephone calls.

\subsection{Data Collection of Lifestyle Factors}

Standardized questionnaires were used to collect lifestyle factors, such as habits of dietary intake and physical activity. Anthropometric measurements included body weight and height. Body mass index (BMI) classification was based on criteria in the AsiaPacific region, and included four groups, as follows: underweight $<18.5 \mathrm{~kg} / \mathrm{m}^{2}$, normal $18.5-22.9 \mathrm{~kg} / \mathrm{m}^{2}$, overweight $23-24.9 \mathrm{~kg} / \mathrm{m}^{2}$, and obese $\geq 25 \mathrm{~kg} / \mathrm{m}^{2}[39]$.

\subsection{Measurements of Sports Activity}

A validated modified Chinese Baecke questionnaire (Table S1) was used to measure the level of physical activities, which consisted of four parts: at work, doing housework, at leisure time (time excluding working and playing sports or exercise), and doing sports [40]. At baseline assessment, patients were asked to report their physical activities in the previous year before cancer diagnosis. During the 18-, 36- and 60-month follow-ups, patients recalled habitual physical activities involvement over the previous 12 months before the interviews.

Sports activities means physical activity in doing sports. We did not include other physical activities such as housework and childcare. Among the four parts of physical activities, sports activity is the one recommended by the World Cancer Research Fund/American Institute for Cancer Research (WCRF/AICR) cancer survivor guidelines and has been extensively explored by previous studies. In order to be more comparable with available evidence in the literature, the present study only analyzes data from one part of the Chinese Baecke questionnaire, namely, sports activities that contribute to overall physical activities. In the questionnaire, each individual who did sports was asked to specify the activities they were involved in categorically (up to 2 types of sports activities) and also to recall the number of hours per week and months per year they had engaged in each activity. The Ainsworth compendium of physical activity provided a MET code for each sport [41]. Based on these data, a score of metabolic equivalent of task (MET)-hours per week could be calculated by multiplying the corresponding MET value of the activity by the time (hours per week) engaged in a particular sports activity [41]. Subsequently, each individual would get a final level of sports activities by summing the score of MET-hours per week of the one or two sports activities they were engaged in.

The recommendation from the ACS and the WCRF/AICR suggests that cancer survivors should be moderately physically active, equivalent to brisk walking, for at least 30 min every day [2,42]. This recommended level of sports activity can be operationalized as being engaged in fast walking or other moderate activities for about 30 min per day for at least 5 days per week. According to the above-mentioned methods for calculation, the recommended level of sports activities is equaled to 10 MET-hours/week (calculated as follows: $4.0 \mathrm{METs} /$ hour $\times 0.5 \mathrm{~h} /$ day $\times 5$ days/week). As such, patients in the present study were divided into three groups according to their level of sports activities, as follows: no (0 MET-hours/week), low-level ( $<10$ MET-hours/week), and high-level ( $\geq 10$ MET-hours/week) sports activities. Patients in the high-level sports activities group belonged to those who met the recommendations for cancer survivors [2,42].

\subsection{Measurement of QoL Using European Organization for Research and Treatment of Cancer Quality of Life Questionnaire Core 30 (EORTC QLQ-C30)}

At each assessment, a globally accepted questionnaire, EORTC QLQ-C30, was used to measure patients' QoL [43]. EORTC QLQ-C30 was developed to assess a range of cancer- 
specific QoL issues [44]. Consisting of thirty cancer-specific questions with multiple-point scales, it includes a global health status, five functional domains (physical, role, emotional, cognitive, and social), and nine symptom profiles (fatigue, nausea and vomiting, pain, dyspnea, insomnia, appetite loss, constipation, diarrhea, and financial difficulties). In the analyses, the multiple-point scale in each item would be transformed into a standard score, ranging from 0 to 100 . Higher scores for global health status and the five functioning domains indicate better QoL, while lower scores for symptom items suggest fewer symptoms or problems [45].

\subsection{Statistical Analysis}

The characteristics of participants were compared among patients who engaged in different levels of sports activity using ANOVA for continuous data and the chi-squared test for categorical data. Univariate and multivariate linear regression analyses were used to investigate the association between levels of sports activities and QoL at 18-, 36- and 60-month follow-up cross-sectionally. As patients were longitudinally followed up at 18,36 , and 60 months, this study further used a generalized estimating equation (GEE) model to evaluate the longitudinal association between sports activities and QoL over the three follow-ups. Similar to repeated-measure ANOVA, the GEE model is a more powerful approach. It takes into consideration the correlations between repeated measurements within the same subjects. As such, the GEE model efficiently investigates the association between participation in sports activities and QoL in a longitudinal manner after adjustment for within-subject correlation [46]. In the analyses, each QoL item is a dependent variable as a function of time and level of sports activities as well as other covariates, which include age at follow-up, education level, household income, AJCC stage, histology, human epidermal-growth-factor receptor 2 (HER 2) status, chemotherapy, endocrine therapy, BMI at follow-up, and presence of menopausal symptoms at follow-up. All statistical analysis was performed using SPSS 26.0; $p$ values $<0.05$ based on two-sided analysis were considered statistically significant.

\section{Results}

3.1. Demographic, Clinical and Lifestyle Characteristics of Patients by Level of Sports Activities at 18-, 36- and 60-Month Follow-Up

In January 2019, the 60-month follow-up assessment was completed. A total of 1462 patients completed the baseline assessment, and $1310(89.6 \%), 1162$ (79.5\%), and 1173 $(80.2 \%)$ patients completed 18-, 36- and 60-month follow-up assessment, respectively. In the present study, patients who had disease recurrence, metastasis, other primary cancers, or incomplete data on sports activities or QoL were excluded; this resulted in 1289, 1125, and 1116 patients included in the analyses at 18-, 36- and 60-month follow-up, respectively. The demographic and clinical characteristics of patients who were included in the present analysis were comparable to the whole cohort. The median intervals between the diagnosis of breast cancer and the 18-, 36-, 60-month follow-ups were 19.0 months (range: 12.1-35.8), 37.9 months (range: $30.1-41.8$ ), and 59.7 months (range: 54.1-66.0), respectively.

At the 18-month assessment, the proportions of patients who belonged to no, low-level, and high-level sports activities groups were $20.7 \%, 45.5 \%$, and $33.8 \%$, respectively, with the mean levels of sports activities being 0,4.2, and 23.4 MET-hours/week, respectively (Table 1). Data at the 18-month follow-up are listed in Table 1. Compared to patients who did not participate in any sports activities, those who engaged in low- or high-level sports activities were more likely to have college or above education (no vs. low-level vs. high-level sports activities group: $9.0 \%$ vs. $17.9 \%$ vs. $15.4 \%$; $p=0.003$ ). In addition, the proportions of patients who were post-menopausal at follow-up were significantly higher in those who were involved in low / high levels of sports activities $(74.9 \% \mathrm{vs} .77 .5 \%$ vs. $82.8 \% ; p=0.027)$. The histology subtypes among the three groups differed slightly; more patients who had low / high sports activities had invasive ductal carcinoma (IDC) $(79.8 \%$ vs. $85.7 \%$ vs. $85.1 \% ; p=0.043)$. Differences were also noted in the proportion of 
patients having HER 2 positive tumors $(21.0 \%$ vs. $28.5 \%$ vs. $26.8 \% ; p<0.001)$ and who received chemotherapy $(70.0 \%$ vs. $78.2 \%$ vs. $77.5 \% ; p=0.027)$. Of note, the proportion of patients with normal BMI was much higher in patients who participated in the higher level of sports activities (41.9\% vs. $42.3 \%$ vs. $53.0 \% ; p=0.001)$. Other demographic and clinical characteristics showed no significant difference between patients participating in different levels of sports activities. 
Table 1. Demographic, clinical, and lifestyle characteristics of patients by level of sports activities at 18-, 36- and 60-month follow-up.

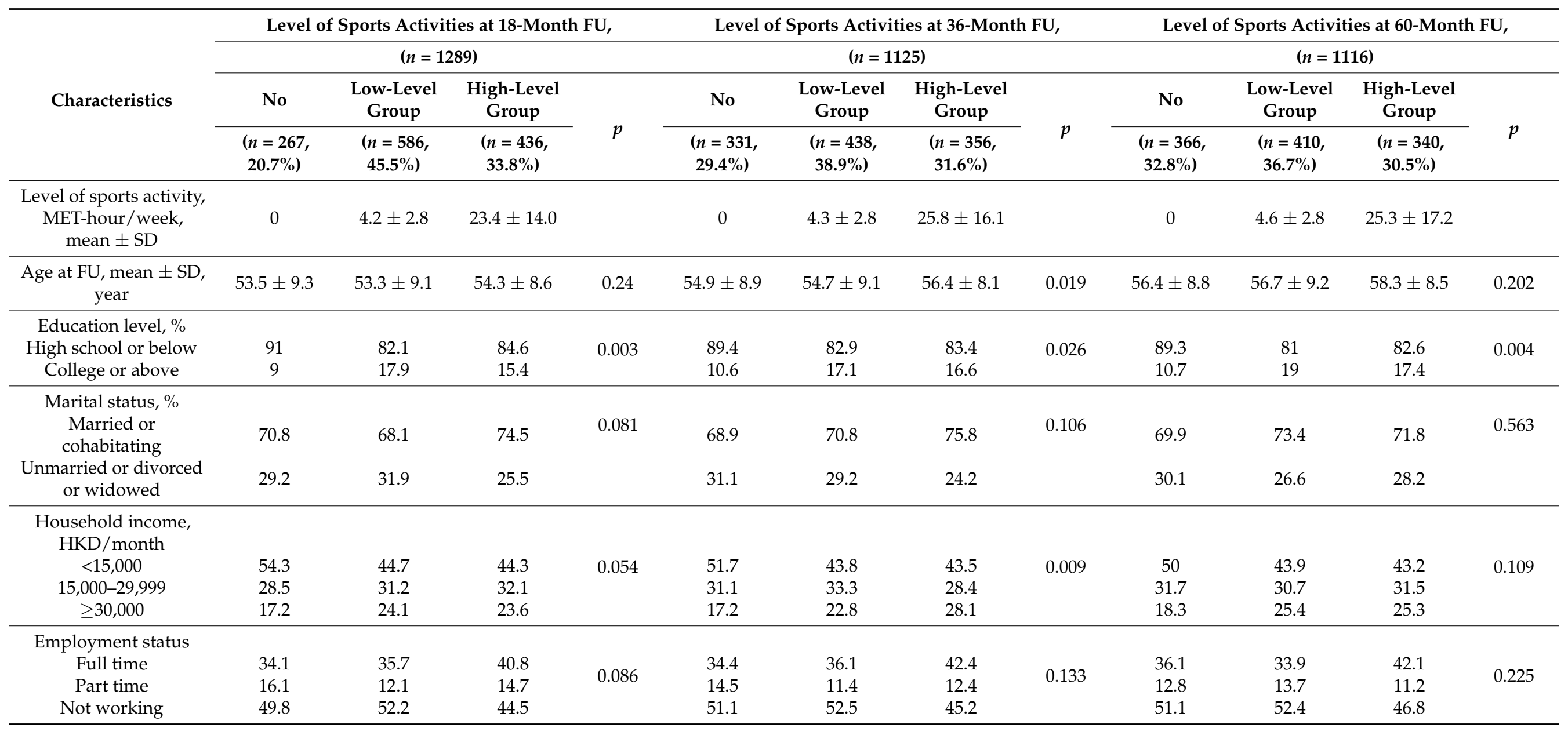


Table 1. Cont.

\begin{tabular}{|c|c|c|c|c|c|c|c|c|c|c|c|c|}
\hline \multirow{4}{*}{ Characteristics } & \multicolumn{4}{|c|}{ Level of Sports Activities at 18-Month FU, } & \multirow{2}{*}{\multicolumn{4}{|c|}{$\begin{array}{l}\text { Level of Sports Activities at 36-Month FU, } \\
\qquad(n=1125)\end{array}$}} & \multirow{2}{*}{\multicolumn{4}{|c|}{$\begin{array}{l}\text { Level of Sports Activities at 60-Month FU, } \\
\qquad(n=1116)\end{array}$}} \\
\hline & \multicolumn{4}{|c|}{$(n=1289)$} & & & & & & & & \\
\hline & No & $\begin{array}{l}\text { Low-Level } \\
\text { Group }\end{array}$ & $\begin{array}{l}\text { High-Level } \\
\text { Group }\end{array}$ & \multirow{2}{*}{$p$} & No & $\begin{array}{l}\text { Low-Level } \\
\text { Group }\end{array}$ & $\begin{array}{l}\text { High-Level } \\
\text { Group }\end{array}$ & \multirow{2}{*}{$p$} & No & $\begin{array}{l}\text { Low-Level } \\
\text { Group }\end{array}$ & $\begin{array}{l}\text { High-Level } \\
\text { Group }\end{array}$ & \multirow{2}{*}{$p$} \\
\hline & $\begin{array}{c}(n=267) \\
20.7 \%)\end{array}$ & $\begin{array}{c}(n=586 \\
45.5 \%)\end{array}$ & $\begin{array}{c}(n=436 \\
33.8 \%)\end{array}$ & & $\begin{array}{c}(n=331 \\
29.4 \%)\end{array}$ & $\begin{array}{c}(n=438 \\
38.9 \%)\end{array}$ & $\begin{array}{c}(n=356 \\
31.6 \%)\end{array}$ & & $\begin{array}{c}(n=366, \\
32.8 \%)\end{array}$ & $\begin{array}{l}(n=410 \\
36.7 \%)\end{array}$ & $\begin{array}{c}(n=340 \\
30.5 \%)\end{array}$ & \\
\hline \multicolumn{13}{|l|}{$\begin{array}{c}\text { No. of comorbidities, } \\
\%\end{array}$} \\
\hline 0 & 55.4 & 61.9 & 62.6 & \multirow[t]{3}{*}{0.273} & 59.2 & 62.8 & 61.5 & \multirow[t]{3}{*}{0.528} & 60.7 & 62.7 & 61.5 & \multirow[t]{3}{*}{0.623} \\
\hline 1 & 28.5 & 25.3 & 25.9 & & 25.7 & 24 & 27.2 & & 24.6 & 26.3 & 25 & \\
\hline$\geq 2$ & 16.1 & 12.8 & 11.5 & & 15.1 & 13.2 & 11.2 & & 14.8 & 11 & 13.5 & \\
\hline \multicolumn{13}{|l|}{$\begin{array}{c}\text { Menopausal status at } \\
\text { FU, \% }\end{array}$} \\
\hline Pre-menopausal & 25.1 & 22.5 & 17.2 & \multirow[t]{2}{*}{0.027} & 24.5 & 22.4 & 16.9 & \multirow[t]{2}{*}{0.039} & 17.5 & 18 & 13.8 & \multirow[t]{2}{*}{0.256} \\
\hline Post-menopausal & 74.9 & 77.5 & 82.8 & & 75.5 & 77.6 & 83.1 & & 82.5 & 82 & 86.2 & \\
\hline \multicolumn{13}{|l|}{ AJCC stage, $\%$} \\
\hline $0-\mathrm{I}$ & 36.3 & 35 & 36.9 & \multirow{3}{*}{0.518} & 35 & 38.6 & 35.1 & \multirow{3}{*}{0.472} & 38.8 & 37.3 & 38.2 & \multirow{3}{*}{0.051} \\
\hline III & 19.9 & 18.6 & 16.3 & & 17.5 & 15.3 & 15.4 & & 18.3 & 14.6 & 12.4 & \\
\hline Missing & 0.7 & 0.7 & 0 & & 0.9 & 0 & 0.6 & & 1.4 & 0 & 0.6 & \\
\hline \multicolumn{13}{|l|}{ Histology, \% } \\
\hline IDC & 79.8 & 85.7 & 85.1 & \multirow{4}{*}{0.043} & 84.3 & 83.1 & 84.3 & \multirow{4}{*}{0.591} & 83.9 & 84.4 & 83.2 & \multirow{4}{*}{0.787} \\
\hline ILC & 1.9 & 2.7 & 3.9 & & 1.5 & 3.7 & 3.7 & & 1.9 & 3.4 & 3.2 & \\
\hline DCIS & 9.7 & 4.9 & 5 & & 7.3 & 6.2 & 5.3 & & 7.1 & 5.6 & 5.6 & \\
\hline Others & 8.6 & 6.7 & 6 & & 6.9 & 7.1 & 6.7 & & 7.1 & 6.6 & 7.9 & \\
\hline \multicolumn{13}{|l|}{ ER status, \% } \\
\hline Positive & 73.1 & 73.1 & 73.4 & \multirow{3}{*}{0.267} & 72.8 & 72.8 & 72.5 & \multirow{3}{*}{0.993} & 75.1 & 71.2 & 73.8 & \\
\hline Negative & 23.2 & 23.5 & 25.2 & & 24.2 & 24.2 & 25 & & 21.3 & 25.6 & 23.5 & 0.662 \\
\hline Missing & 3.7 & 3.4 & 1.4 & & 3 & 3 & 2.5 & & 3.6 & 3.2 & 2.6 & \\
\hline PR status, \% & & & & & & & & & & & & \\
\hline Positive & 59.2 & 55.8 & 54.8 & & 55.3 & 57.5 & 42.4 & & 56 & 55.6 & 55.9 & \\
\hline Negative & 37.1 & 39.9 & 43.8 & 0.05 & 41.1 & 39.3 & 55.1 & 0.838 & 39.9 & 41.2 & 41.2 & 0.924 \\
\hline Missing & 3.7 & 4.3 & 1.4 & & 3.6 & 3.2 & 2.5 & & 4.1 & 3.2 & 2.9 & \\
\hline
\end{tabular}


Table 1. Cont.

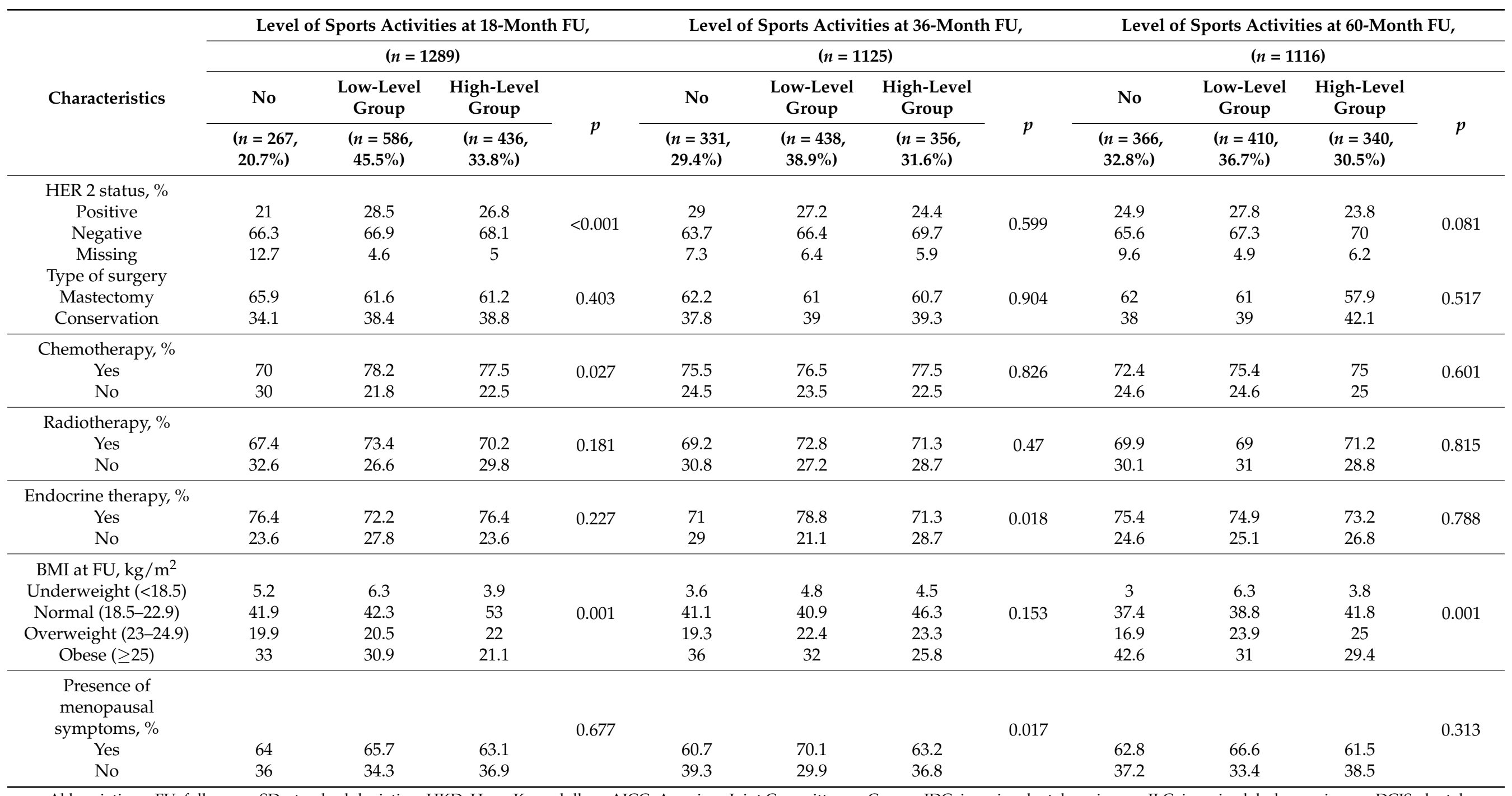

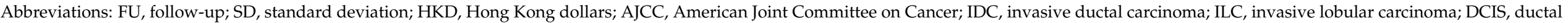
carcinoma in situ; ER, estrogen receptor; PR, progesterone receptor; HER 2, human epidermal-growth-factor receptor 2; BMI, body mass index; MET, metabolic equivalent of task. 
Similar analyses were conducted at the 36-month follow-up. The proportions of patients having no, low-level, and high-level sports activities were $29.4 \%, 38.9 \%$, and 31.6\%, respectively. The significant differences observed above in education level (patients who had college or above: $10.6 \%$ vs. $17.1 \%$ vs. $16.6 \% ; p=0.026$ ) and menopausal status (patients who were post-menopausal: $75.5 \%$ vs. $77.6 \%$ vs. $83.1 \% ; p=0.039$ ) were also noted at the 36-month follow-up. In addition, patients who were involved in high-level sports activities at the 36-month follow-up tended to be older (mean age: 54.9 vs. 54.7 vs. $56.4 ; p=0.019$ ) and had higher household income (patients with household income $\geq 30,000 \mathrm{HKD} / \mathrm{month}$ : $17.2 \%$ vs. $22.8 \%$ vs. $28.1 \%$; $p=0.009$ ) than those who did not engage in any sports activities. Moreover, patients who had low-level sports activities at the 36-month follow-up were more likely to have endocrine therapy $(71.0 \%$ vs. $78.8 \%$ vs. $71.3 \% ; p=0.018)$ and report menopausal symptoms $(60.7 \%$ vs. $70.1 \%$ vs. $63.2 \% ; p=0.017)$ than those who did not engage in any sports activities.

At the 60-month follow-up, the proportions of patients who belonged to the no, low-level, and high-level sports activities groups were similar to those in the 36-month follow-up, with the corresponding figures being $32.8 \%, 36.7 \%$, and $30.5 \%$, respectively. When compared to patients who did not engage in any sports activity, those who were engaged in low- or high-level sports activities were more likely to have college or above education $(10.7 \%$ vs. $19.0 \%$ vs. $17.4 \%$; $p=0.004)$. In addition, the proportion of patients with normal BMI were higher in those who were engaged in low- and high-level sports activities $(37.4 \%$ vs. $38.8 \%$ vs. $41.8 \% ; p=0.001)$. No significant differences were found regarding other characteristics.

3.2. Linear Regression Model to Investigate the Associations between Level of Sports Activities Participation and QoL Scores at 18-, 36- and 60-Month Follow-Up Based on Cross-Sectional Analyses

At the 18-month follow-up, 1289 patients were included in the analysis. Multivariate linear regression models with adjustment for socio-demographic, clinical, and lifestyle variables indicated that when compared to patients who had no sports activity, patients with a higher level of sports activities had significantly better QoL in global health status/QoL ( $p$ for trend $<0.001$, Table 2), physical functioning ( $p$ for trend $=0.008$ ), role functioning ( $p$ for trend $=0.037$ ), and emotional functioning ( $p$ for trend $=0.013$ ) as well as less symptoms in fatigue $(p$ for trend $<0.001)$ and dyspnea $(p$ for trend $=0.014)$. 


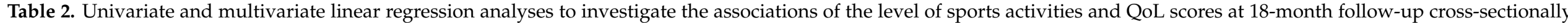
$(n=1289)$.

\begin{tabular}{|c|c|c|c|c|c|c|c|c|c|c|}
\hline \multirow{3}{*}{ EORTC QLQ-C30 } & \multicolumn{5}{|c|}{ Crude } & \multicolumn{5}{|c|}{ Adjusted } \\
\hline & \multicolumn{2}{|c|}{$\begin{array}{c}\text { Low-Level Group } \\
(n=438)\end{array}$} & \multicolumn{2}{|c|}{$\begin{array}{c}\text { High-Level Group } \\
\quad(n=356)\end{array}$} & \multirow{2}{*}{$p$ for Trend } & \multicolumn{2}{|c|}{$\begin{array}{c}\text { Low-Level Group } \\
(n=438)\end{array}$} & \multicolumn{2}{|c|}{$\begin{array}{l}\text { High-Level Group } \\
(n=356)\end{array}$} & \multirow[t]{2}{*}{$p$ for Trend } \\
\hline & Mean Difference & $95 \% \mathrm{CI}$ & Mean Difference & $95 \% \mathrm{CI}$ & & Mean Difference & $95 \% \mathrm{CI}$ & Mean Difference & $95 \% \mathrm{CI}$ & \\
\hline $\begin{array}{l}\text { Global Health } \\
\text { status/QoL }\end{array}$ & 1.43 & 1.08 to 3.95 & 5.44 & 2.79 to 8.09 & $<0.001$ & 1.32 & 1.06 to 3.69 & 5.07 & 2.56 to 7.57 & $<0.001$ \\
\hline \multicolumn{11}{|c|}{ Functioning } \\
\hline $\begin{array}{c}\text { Physical } \\
\text { Functioning }\end{array}$ & -0.31 & -1.98 to 1.37 & 2.21 & 0.46 to 3.97 & 0.004 & -0.38 & -1.93 to 1.16 & 1.86 & 0.23 to 3.50 & 0.008 \\
\hline Role Functioning & -0.32 & -2.43 to 1.78 & 1.71 & -0.50 to 3.93 & 0.076 & -0.05 & -2.11 to 2.00 & 2.02 & -0.15 to 4.19 & 0.037 \\
\hline $\begin{array}{l}\text { Emotional } \\
\text { Functioning }\end{array}$ & 2.41 & -0.27 to 5.10 & 3.22 & 0.39 to 6.05 & 0.033 & 2.97 & 0.57 to 5.38 & 3.48 & 0.94 to 6.02 & 0.013 \\
\hline $\begin{array}{c}\text { Cognitive } \\
\text { Functioning }\end{array}$ & 0.18 & -2.56 to 2.92 & 1.06 & -1.82 to 3.94 & 0.432 & 0.14 & -2.48 to 2.75 & 0.81 & -1.96 to 3.57 & 0.531 \\
\hline Social Functioning & 0.41 & -1.79 to 2.61 & 0.44 & -1.87 to 2.76 & 0.730 & 0.70 & -1.45 to 2.86 & 0.40 & -1.87 to 2.68 & 0.805 \\
\hline \multicolumn{11}{|c|}{ Symptoms } \\
\hline Fatigue & -0.56 & -3.14 to 2.30 & -4.79 & -7.80 to -1.79 & $<0.001$ & -0.90 & -3.53 to 1.73 & -4.31 & -7.09 to -1.54 & $<0.001$ \\
\hline $\begin{array}{l}\text { Nausea and } \\
\text { vomiting }\end{array}$ & -0.15 & -1.07 to 0.78 & -0.54 & -1.52 to 0.43 & 0.242 & -0.10 & -1.03 to 0.84 & -0.30 & -1.28 to 0.69 & 0.530 \\
\hline Dyspnea & -0.60 & -3.05 to 1.85 & -3.41 & -5.99 to -0.83 & 0.005 & -0.88 & -3.28 to 1.52 & -2.98 & -5.51 to -0.48 & 0.014 \\
\hline Insomnia & 3.41 & -0.71 to 7.52 & 0.79 & -3.54 to 5.13 & 0.958 & 3.05 & -0.84 to 6.94 & 0.57 & -3.55 to 4.68 & 0.962 \\
\hline Loss of appetite & -0.83 & -2.76 to 1.10 & -2.05 & -4.08 to -0.02 & 0.040 & -0.46 & -2.39 to 1.47 & -1.42 & -3.47 to 0.62 & 0.148 \\
\hline Constipation & -1.94 & -4.81 to 0.92 & -2.58 & -5.59 to 0.44 & 0.109 & -1.82 & -4.72 to 1.09 & -2.54 & -5.61 to 0.54 & 0.119 \\
\hline Diarrhea & 1.57 & -0.22 to 3.35 & -0.51 & -2.39 to 1.37 & 0.329 & 1.15 & -0.64 to 2.94 & -0.66 & -2.56 to 1.23 & 0.286 \\
\hline Financial impact & 0.35 & -3.05 to 3.75 & 0.14 & -3.44 to 3.71 & 0.968 & 1.28 & -2.01 to 4.57 & 1.67 & -1.81 to 5.15 & 0.372 \\
\hline
\end{tabular}

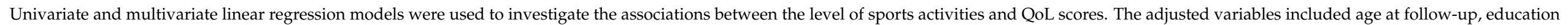

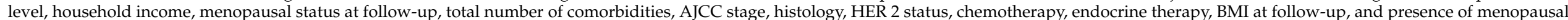

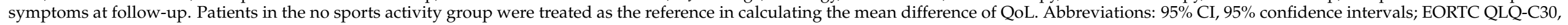

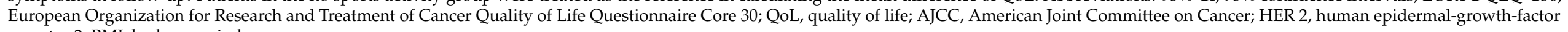
receptor 2; BMI, body mass index. 
At the 36-month follow-up, 1125 patients were included in the analysis. Similar to the associations noted at the 18-month follow-up; when compared to patients who had no sports activity, women with a higher level of sports activities reported better global health status/QoL ( $p$ for trend $=0.028$, Table 3$)$, physical functioning ( $p$ for trend $=0.003$ ), and emotional functioning ( $p$ for trend $=0.006$ ). In addition, higher participation in sports activities was significantly related to fewer symptoms of fatigue ( $p$ for trend $<0.001$ ) and constipation ( $p$ for trend $=0.002$ ). 


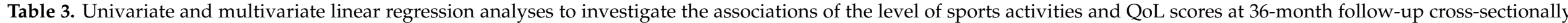
$(n=1125)$.

\begin{tabular}{|c|c|c|c|c|c|c|c|c|c|c|}
\hline \multirow{3}{*}{ EORTC QLQ-C30 } & \multicolumn{5}{|c|}{ Crude } & \multicolumn{5}{|c|}{ Adjusted } \\
\hline & \multicolumn{2}{|c|}{$\begin{array}{c}\text { Low-Level Group } \\
(n=586)\end{array}$} & \multicolumn{2}{|c|}{$\begin{array}{l}\text { High-Level Group } \\
\quad(n=436)\end{array}$} & \multirow{2}{*}{$p$ for Trend } & \multicolumn{2}{|c|}{$\begin{array}{c}\text { Low-level Group } \\
\quad(n=586)\end{array}$} & \multicolumn{2}{|c|}{$\begin{array}{l}\text { High-Level Group } \\
\quad(n=436)\end{array}$} & \multirow[t]{2}{*}{$p$ for Trend } \\
\hline & Mean Difference & $95 \% \mathrm{CI}$ & Mean Difference & $95 \% \mathrm{CI}$ & & Mean Difference & $95 \% \mathrm{CI}$ & Mean Difference & $95 \% \mathrm{CI}$ & \\
\hline $\begin{array}{l}\text { Global Health } \\
\text { status/QoL }\end{array}$ & -0.59 & -3.20 to 2.02 & 3.17 & 0.43 to 5.91 & 0.021 & -0.05 & -2.50 to 2.40 & 2.85 & 0.27 to 5.43 & 0.028 \\
\hline \multicolumn{11}{|c|}{ Functioning } \\
\hline $\begin{array}{c}\text { Physical } \\
\text { Functioning }\end{array}$ & -0.61 & -2.40 to 1.18 & 3.05 & 1.17 to 4.93 & 0.001 & -0.39 & -2.08 to 1.30 & 2.67 & 0.90 to 4.45 & 0.003 \\
\hline Role Functioning & -0.32 & -2.52 to 1.87 & 2.08 & -0.23 to 4.38 & 0.072 & 0.28 & -1.88 to 2.44 & 1.97 & -0.31 to 4.24 & 0.087 \\
\hline $\begin{array}{l}\text { Emotional } \\
\text { Functioning }\end{array}$ & -0.16 & -2.78 to 2.47 & 3.11 & 0.36 to 5.86 & 0.002 & 1.60 & -0.75 to 3.95 & 3.46 & 0.99 to 5.93 & 0.006 \\
\hline $\begin{array}{c}\text { Cognitive } \\
\text { Functioning }\end{array}$ & -0.43 & -3.22 to 2.36 & 0.76 & -2.16 to 3.69 & 0.598 & 0.69 & -1.88 to 3.26 & 0.46 & -2.25 to 3.17 & 0.748 \\
\hline Social Functioning & -0.65 & -2.71 to 1.42 & 1.68 & -0.49 to 3.84 & 0.119 & -0.23 & -2.28 to 1.82 & 1.37 & -0.79 to 3.52 & 0.205 \\
\hline \multicolumn{11}{|c|}{ Symptoms } \\
\hline Fatigue & 0.05 & -2.94 to 3.04 & -5.19 & -8.32 to -2.05 & 0.001 & -1.24 & -3.91 to 1.44 & -5.05 & -7.86 to -2.23 & $<0.001$ \\
\hline $\begin{array}{l}\text { Nausea and } \\
\text { vomiting }\end{array}$ & 0.52 & -0.86 to 1.89 & -0.38 & -1.82 to 1.06 & 0.587 & 0.42 & -0.96 to 1.80 & -0.24 & -1.70 to 1.21 & 0.726 \\
\hline Dyspnea & 0.83 & -1.92 to 3.57 & -0.46 & -3.34 to 2.42 & 0.739 & 0.43 & -2.21 to 3.07 & 0.22 & -2.56 to 3.00 & 0.881 \\
\hline Insomnia & 0.99 & -3.20 to 5.18 & -2.05 & -6.44 to 2.34 & 0.347 & -0.85 & -4.77 to 3.07 & -2.60 & -6.73 to 1.53 & 0.214 \\
\hline Loss of appetite & 0.23 & -1.94 to 2.39 & -1.86 & -4.14 to 0.41 & 0.102 & -0.09 & -2.26 to 2.07 & -1.83 & -4.11 to 0.44 & 0.109 \\
\hline Constipation & -3.06 & -6.15 to 0.04 & -5.25 & -8.49 to -2.00 & 0.002 & -3.75 & -6.83 to -0.68 & -5.13 & -8.34 to -1.88 & 0.002 \\
\hline Diarrhea & 0.23 & -1.91 to 2.37 & -1.02 & -3.26 to 1.22 & 0.362 & -0.19 & -2.33 to 1.94 & -1.15 & -3.41 to 1.10 & 0.309 \\
\hline Financial impact & 2.12 & -0.77 to 5.00 & 0.55 & -2.47 to 3.57 & 0.746 & 2.34 & -0.44 to 5.12 & 1.43 & -1.50 to 4.37 & 0.356 \\
\hline
\end{tabular}

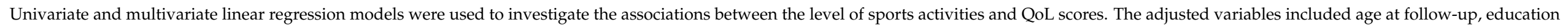

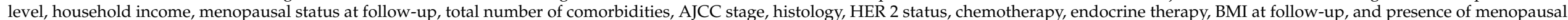

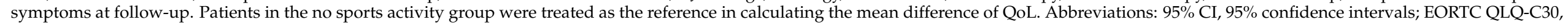

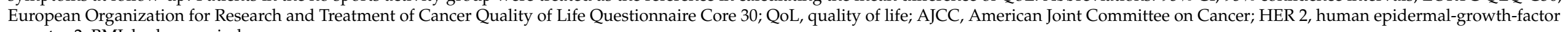
receptor 2; BMI, body mass index. 
A total of 1116 patients were included in the analyses at the 60-month follow-up. Similar associations were noted at this follow-up. Compared with those who had no sports activity, those who participated in a higher level of sports activities reported higher scores in global health status/QoL ( $p$ for trend $<0.001$, Table 4 ) and physical functioning ( $p$ for trend $=0.020$ ); on the other hand, they also had higher scores (more severe symptoms) in insomnia ( $p$ for trend $=0.034$ ). 


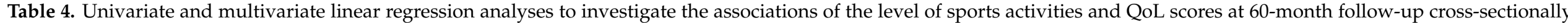
$(n=1116)$.

\begin{tabular}{|c|c|c|c|c|c|c|c|c|c|c|}
\hline \multirow{3}{*}{ EORTC QLQ-C30 } & \multicolumn{5}{|c|}{ Crude } & \multicolumn{5}{|c|}{ Adjusted } \\
\hline & \multicolumn{2}{|c|}{$\begin{array}{c}\text { Low-Level Group } \\
(n=410)\end{array}$} & \multicolumn{2}{|c|}{$\begin{array}{c}\text { High-Level Group } \\
\quad(n=340)\end{array}$} & \multirow{2}{*}{$p$ for Trend } & \multicolumn{2}{|c|}{$\begin{array}{c}\text { Low-Level Group } \\
\quad(n=410)\end{array}$} & \multicolumn{2}{|c|}{$\begin{array}{c}\text { High-Level Group } \\
(n=340)\end{array}$} & \multirow[t]{2}{*}{$p$ for Trend } \\
\hline & Mean Difference & $95 \% \mathrm{CI}$ & Mean Difference & $95 \% \mathrm{CI}$ & & Mean Difference & $95 \% \mathrm{CI}$ & Mean Difference & $95 \% \mathrm{CI}$ & \\
\hline $\begin{array}{l}\text { Global Health } \\
\text { status/QoL }\end{array}$ & 1.13 & -1.35 to 3.61 & 6.20 & 3.60 to 8.80 & $<0.001$ & 1.43 & -0.92 to 3.78 & 5.74 & 3.26 to 8.21 & $<0.001$ \\
\hline \multicolumn{11}{|c|}{ Functioning } \\
\hline $\begin{array}{c}\text { Physical } \\
\text { Functioning }\end{array}$ & -0.13 & -1.90 to 1.63 & 2.58 & 0.73 to 4.43 & 0.007 & -0.22 & -1.87 to 1.43 & 2.07 & 0.33 to 3.81 & 0.020 \\
\hline Role Functioning & 0.49 & -1.65 to 2.64 & 0.60 & -1.65 to 2.85 & 0.597 & 0.97 & -1.18 to 3.12 & 0.44 & -1.82 to 2.71 & 0.697 \\
\hline $\begin{array}{l}\text { Emotional } \\
\text { Functioning }\end{array}$ & 0.06 & -2.45 to 2.56 & 1.92 & 0.71 to 4.54 & 0.157 & 0.62 & -1.66 to 2.91 & 1.40 & -1.01 to 3.80 & 0.253 \\
\hline $\begin{array}{l}\text { Cognitive } \\
\text { Functioning }\end{array}$ & -0.34 & -3.08 to 2.40 & 0.66 & -2.21 to 3.53 & 0.661 & -0.04 & -2.61 to 2.52 & -0.05 & -2.75 to 2.65 & 0.971 \\
\hline Social Functioning & -0.53 & -2.43 to 1.36 & -0.18 & -2.16 to 1.81 & 0.852 & -0.53 & -2.39 to 1.34 & -0.95 & -2.92 to 1.02 & 0.342 \\
\hline \multicolumn{11}{|c|}{ Symptoms } \\
\hline Fatigue & 0.55 & -2.25 to 3.34 & -1.79 & -4.72 to 1.13 & 0.240 & -0.03 & -2.56 to 2.50 & -0.95 & -3.62 to 1.71 & 0.483 \\
\hline $\begin{array}{l}\text { Nausea and } \\
\text { vomiting }\end{array}$ & 0.27 & -0.90 to 1.43 & -0.26 & -1.48 to 0.96 & 0.692 & 0.37 & -0.81 to 1.55 & 0.09 & -1.15 to 1.33 & 0.886 \\
\hline Dyspnea & -0.26 & -2.79 to 2.27 & -1.14 & -3.79 to 1.51 & 0.402 & -0.13 & -2.59 to 2.33 & 0.10 & -2.49 to 2.70 & 0.938 \\
\hline Insomnia & 4.56 & 0.45 to 8.67 & 3.69 & -0.61 to 8.00 & 0.086 & 4.07 & 0.20 to 7.94 & 4.40 & 0.32 to 8.48 & 0.034 \\
\hline Loss of appetite & 0.42 & -1.49 to 2.34 & -2.19 & -4.20 to -0.19 & 0.036 & 0.43 & -1.47 to 2.33 & -1.62 & -3.62 to 0.38 & 0.115 \\
\hline Constipation & -0.93 & -4.07 to 2.22 & -3.54 & -6.84 to -0.25 & 0.036 & -1.63 & -4.79 to 1.53 & -3.32 & -6.64 to 0.01 & 0.050 \\
\hline Diarrhea & 0.22 & -1.88 to 2.32 & -1.38 & -3.58 to 0.81 & 0.225 & 0.23 & -1.88 to 2.34 & -0.85 & -3.08 to 1.37 & 0.455 \\
\hline Financial impact & -0.31 & -2.99 to 2.37 & -1.38 & -4.19 to 1.43 & 0.340 & 0.14 & -2.48 to 2.75 & 0.01 & -2.75 to 2.76 & 0.997 \\
\hline
\end{tabular}

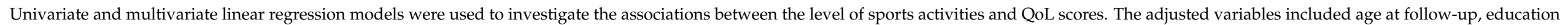

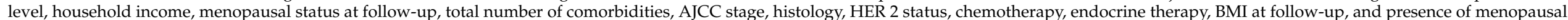

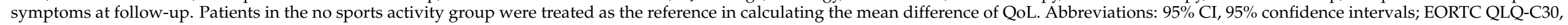

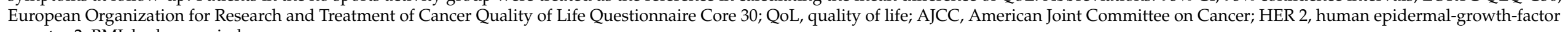
receptor 2; BMI, body mass index. 
3.3. GEE Analyses to Investigate the Association between Level of Sports Activity and QoL Sports over the Three Follow-Ups Longitudinally

Based on the GEE analysis, after controlling for three follow-up time-points and other covariables, when compared to those who had no sports activity, the higher level of sports activities was associated with better global health status/QoL, physical functioning, role functioning, and emotional functioning (Table 5). For instance, compared to patients who did not participate in sports activity, patients who participated in low-level and high-level sports activities reported higher scores in global health status/QoL (mean difference: 0.97 and 4.53 , respectively; $p$ for trend $<0.0001$ ). In terms of symptom items, the higher level of sports activities was associated with lower symptom scores (less severe symptoms) in fatigue, pain, loss of appetite, and constipation. For instance, compared to patients who did not participate in sports activity, patients who participated in low-level and highlevel sports activities reported lower scores in fatigue (mean difference: -0.73 and -3.52 , respectively; $p$ for trend $<0.0001$ ). In addition, interactions between the level of sports activities and follow-up time-points were also tested in the GEE models, and no significant interaction was noted ( $p$ for interaction $>0.05$ for all). 


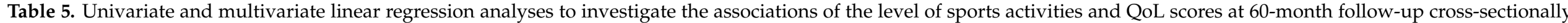
$(n=1116)$.

\begin{tabular}{|c|c|c|c|c|c|c|c|c|c|c|}
\hline \multirow{3}{*}{ EORTC QLQ-C30 } & \multicolumn{5}{|c|}{ Model 1} & \multicolumn{5}{|c|}{ Model 2} \\
\hline & \multicolumn{2}{|c|}{$\begin{array}{l}\text { Low-Level Group } \\
\quad(n=410)\end{array}$} & \multicolumn{2}{|c|}{$\begin{array}{c}\text { High-Level Group } \\
(n=340)\end{array}$} & \multirow[t]{2}{*}{$p$ for Trend } & \multicolumn{2}{|c|}{$\begin{array}{l}\text { Low-Level Group } \\
\quad(n=410)\end{array}$} & \multicolumn{2}{|c|}{$\begin{array}{c}\text { High-Level Group } \\
(n=340)\end{array}$} & \multirow[t]{2}{*}{$p$ for Trend } \\
\hline & Mean Difference & $95 \% \mathrm{CI}$ & Mean Difference & $95 \% \mathrm{CI}$ & & Mean Difference & $95 \% \mathrm{CI}$ & Mean Difference & $95 \% \mathrm{CI}$ & \\
\hline $\begin{array}{l}\text { Global Health } \\
\text { status/QoL }\end{array}$ & 0.67 & -1.0 to 2.34 & 4.9 & 3.03 to 6.80 & $<0.001$ & 0.97 & -0.51 to 2.45 & 4.53 & 2.85 to 6.20 & $<0.001$ \\
\hline \multicolumn{11}{|c|}{ Functioning } \\
\hline $\begin{array}{c}\text { Physical } \\
\text { Functioning }\end{array}$ & -0.33 & -1.52 to 0.86 & 2.61 & 1.38 to 3.83 & $<0.001$ & -0.27 & -1.35 to 0.80 & 2.25 & 1.16 to 3.34 & $<0.001$ \\
\hline Role Functioning & -0.09 & -1.50 to 1.32 & 1.49 & -0.01 to 3.00 & 0.042 & 0.29 & -1.09 to 1.66 & 1.53 & 0.09 to 2.97 & 0.030 \\
\hline $\begin{array}{l}\text { Emotional } \\
\text { Functioning }\end{array}$ & 0.78 & -0.98 to 2.53 & 1.92 & 0.68 to 4.62 & 0.007 & 1.77 & 0.27 to 3.28 & 2.75 & 1.10 to 4.40 & 0.001 \\
\hline $\begin{array}{l}\text { Cognitive } \\
\text { Functioning }\end{array}$ & -0.20 & -2.06 to 1.66 & 0.88 & -1.27 to 2.88 & 0.419 & 0.26 & -1.42 to 1.94 & 0.54 & -1.31 to 2.38 & 0.567 \\
\hline Social Functioning & -0.24 & -1.52 to 1.04 & 0.60 & -0.85 to 2.05 & 0.389 & -0.02 & -1.23 to 1.19 & 0.30 & -1.05 to 1.66 & 0.644 \\
\hline \multicolumn{11}{|c|}{ Symptoms } \\
\hline Fatigue & 0.08 & -1.90 to 2.07 & -3.90 & -6.03 to -1.77 & $<0.001$ & -0.73 & -2.42 to 0.97 & -3.52 & -5.28 to -1.75 & $<0.001$ \\
\hline $\begin{array}{l}\text { Nausea and } \\
\text { vomiting }\end{array}$ & 0.21 & -0.49 to 0.91 & -0.37 & -1.08 to 0.33 & 0.261 & 0.22 & -0.48 to 0.92 & -0.14 & -0.82 to 0.54 & 0.631 \\
\hline Dyspnea & 0.08 & -1.57 to 1.73 & -1.68 & -3.43 to 0.07 & 0.049 & -0.05 & -1.59 to 1.50 & -0.91 & -2.55 to 0.73 & 0.051 \\
\hline Insomnia & 3.05 & 0.37 to 5.72 & 0.82 & -2.16 to 3.80 & 0.682 & 2.06 & -0.32 to 4.44 & 0.64 & -1.99 to 3.27 & 0.713 \\
\hline Loss of appetite & -0.08 & -1.37 to 1.20 & -1.98 & -3.22 to -0.75 & 0.001 & -0.13 & -1.38 to 1.12 & -1.62 & -2.83 to -0.40 & 0.006 \\
\hline Constipation & -2.04 & -4.14 to 0.06 & -3.74 & -6.02 to -1.47 & 0.001 & -2.45 & -4.49 to -0.42 & -3.64 & -5.83 to -1.44 & 0.001 \\
\hline Diarrhea & 0.66 & -0.57 to 1.90 & -1.02 & -2.26 to 0.21 & 0.078 & 0.44 & -0.77 to 1.64 & -0.98 & -2.19 to 0.22 & 0.082 \\
\hline Financial impact & 0.67 & -1.28 to 2.62 & -0.22 & -2.33 to 1.90 & 0.798 & 1.17 & -0.67 to 3.02 & 1.09 & -0.88 to 3.06 & 0.302 \\
\hline
\end{tabular}

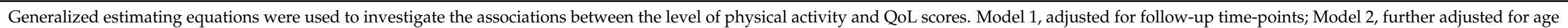

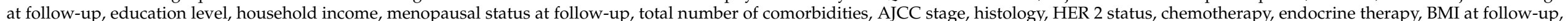

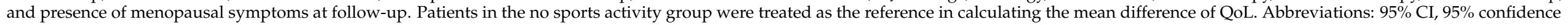

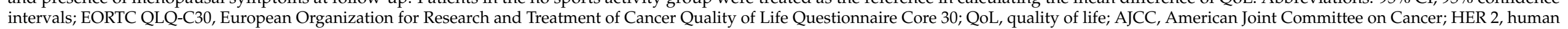
epidermal-growth-factor receptor 2; BMI, body mass index. 


\section{Discussion}

Based on a cohort study, the present report found that regular participation in sports activities after breast cancer diagnosis was significantly associated with better general health status/QoL and physical functioning during the first five years of survival. Furthermore, the positive association between sports activities and QoL persisted over time. Using the GEE model to control for the follow-up time-points, the findings indicated that women engaged in higher-level sports activities, especially meeting the sports activities recommendation for cancer survivors ( $\geq 10$ MET-hours/week), tended to have better general health status/QoL, physical functioning, role functioning, and emotional functioning as well as fewer symptoms of fatigue, pain, loss of appetite, and constipation.

This study compared the characteristics of patients who participated in different levels of sports activities. Of note, patients who attended college or above were more likely to involve in higher levels of sports activities at all three follow-ups. This phenomenon has also been reported in a previous study [20]. This study also showed that a higher proportion of women who were post-menopausal participated in higher levels of sports activities, suggesting that they might have had more spare time, which allowed them to focus more on their lifestyle habits. They may also be seeking potential maneuvers, such as sports activities, to relieve menopausal symptoms. Moreover, patients with normal BMI were associated with higher levels of sports activities participation. Patients with normal BMI might be more health-conscious; on the other hand, normal BMI could be the result of regular sports activities.

There has been a series of interventional studies investigating whether short-term, structured sports activities interventions can improve the QoL of breast cancer patients. A meta-analysis by Lahart et al. assessed the benefit of sports activities interventions after adjuvant therapy for breast cancer patients [14]; 63 trials involving 5761 women were included and well-randomized to exercise or control groups. While some studies only included aerobic sports activities or resistance training, others adopted both. The results suggest that interventions with sports activities might have a small-to-moderate benefit on overall QoL and emotional, physical, and social function as well as a reduction in anxiety [14]. Covington et al., who undertook a meta-analysis that included 31 studies, reported that community-based exercise programs are also effective for improving QoL in adult cancer survivors [15]. In another recently published systematic review by Zhang et al., which included 36 studies and 3914 participants, the type of sports activities were categorized into three modes: aerobic, resistance, and a combination of aerobic and resistance. All three modes of sports activities intervention showed a significant positive effect on QoL between groups [16].

In addition to evidence obtained from interventional studies, observational studies have also evaluated the beneficial effects of sports activities on QoL in breast cancer survivors. The Health, Eating, Activity, and Lifestyle (HEAL) study enrolled a multi-ethnic cohort of 729 early-stage breast cancer survivors in the United States (US) [21]. Participation in sports activities was evaluated for around 2.5 years after diagnosis, with QoL being assessed 6-12 months thereafter using the Medical Outcomes Study Short Form Survey (SF-36). Breast cancer survivors who partook in $\geq 2.5 \mathrm{~h} /$ week of moderate to vigorous sports activities were categorized as meeting recommendations by the American College of Sports Medicine. The results showed that women who met the recommendation had better vitality, social functioning, emotional roles, and global QoL [21]. Chen et al. investigated the association between post-diagnosis sports activities and QoL among Chinese breast cancer survivors who participated in the Shanghai Breast Cancer Survival Study (SBCSS). Participants reported their level of sports activities at 3 time-points, i.e., 6, 18, and 36 months after diagnosis [20]. The General Quality of Life Inventory-74 (GQOLI-74) was used to assess QoL at 6- and 36-month follow-up after diagnosis. Patients were categorized into three groups according to their level of sports activities: a no sports activity group, a low-level group (<8.3 MET-hours/week), and a high-level group ( $\geq 8.3$ MET-hours/week) based on the US Department of Health and Human Services national recommendation 
for recreational physical activity [47]. At the 6-month follow-up, a higher level of sports activities was associated with better physical, psychological, and social well-being as well as total QoL. Further, the average level of sports activities over the 36 months after diagnosis was positively associated with total QoL as well as physical, psychological, and social well-being [20]. Additionally, a few cross-sectional studies have also investigated the association between sports activities and QoL among breast cancer survivors $[18,19]$. Blanchard et al. reported that US women who met the ACS recommendations on sports activities had better QoL than those who did not $[18,19]$. In another study, 3344 Chinese women with breast cancer were included [25]. Patients who were engaged in moderateintensity sports activities for at least 30 min once every week in the past month were defined as exercisers, and the others were non-exercisers. Compared to non-exercisers, exercisers had significantly higher scores of physical, role, and emotional functioning as well as global health status; they also reported milder symptoms of nausea and vomiting, pain, dyspnea, and appetite loss [25]. More recently, a cross-sectional study among 214 breast and colorectal cancer survivors in Korea also supported the association between higher levels of sports activities and better QoL [29]. Similar to previous studies, the present study provides important data from an Asian population, supporting that regular engagement in sports activities, especially exercise that meets the recommended exercise level, was associated with better QoL in several items. Of note, the questionnaires used to measure QoL in earlier studies were not identical. Nonetheless, the significant associations between a higher level of sports activities participation and global health status, physical functioning, role functioning, and emotional functioning in the present study were consistent with those reported in the US population [21]. However, the significant association between a higher level of sports activities participation and social functioning in the US population was not observed in the present study.

For interventional studies, it is notable that the exercise engagement was supervised, encouraged, and monitored in the process of research. Compared to interventional studies, observational studies evaluated patients' engagement in sports activities in unsupervised conditions. This has the advantage of capturing patients' real-life participation in sports activities as part of their routine daily lifestyle. Hence, data from observational studies also provide valuable information to support the benefits of regular sports activities. The present study utilized prospective data from a cohort study and investigated the association between participation in sports activities and QoL during an important time window, namely, the first five years of survival. During this stage, breast cancer patients will adapt from an immediate to a long-term cancer survivorship. The present study shows that only about $30 \%$ of local Chinese women with breast cancer achieve the recommended level of sports activities. As such, like their Western counterparts, they should be encouraged to increase their sports activities.

There are a few possible biological mechanisms that mediate potential beneficial effects on QoL with the engagement of sports activities. These include cardiovascular and pulmonary adaptations, improved musculoskeletal strength, and maintenance of mobility and independence $[48,49]$. In addition, sports activities can indirectly influence psychosocial well-being via self-efficacy and health status indicators [50]. Further, a growing number of studies have shown that higher participation in sports activities is associated with better long-term outcomes in women with breast cancer [7,51-57]. A number of proposed mechanisms have been raised to explain the role of sports activities in modifying disease progression; these include changes in insulin-like growth factor (IGF) levels, immune regulation, and changes in metabolic hormone levels [58-60]. Follow-up of the cohort in the present study would provide important evidence about the potential benefit of regular engagement in sports activities on long-term outcomes among Chinese breast cancer survivors.

The present study has several strengths. Firstly, it was based on a prospective study with a relatively large sample size. During each assessment, interviewers collected detailed socio-demographic, clinical, and lifestyle factors, and potential confounders were adjusted 
in multivariate analyses. Secondly, this study investigated the association between participation in sports activities and QoL in a longitudinal manner at three time-points during the first five years of survival among Chinese women with breast cancer, which is an important time window for cancer survivors. In addition, the GEE model used in this study allows for the control of follow-up time-points and strengthens the reliability of the findings that regular sports activities are beneficial. Thirdly, women with breast cancer showed distinct BMI profiles as well as lifestyles from their Western counterparts. As evidence on the association between sports engagement and QoL among Asian populations is limited, this study provides a piece of important evidence for patients in our geographical region. Fourthly, data from observational studies are reflective of real-life habitual practice in our studied population. However, a few limitations exist in the present study. Firstly, while the modified Chinese Baecke questionnaire includes physical activity at work, when doing housework, at leisure time, and when doing sports, the present study only used one part of the data. Secondly, the modified Chinese Baecke questionnaire has been validated in a random sample of the Hong Kong adult population and has not been specifically validated in cancer patients. Additionally, this questionnaire was based on self-reporting, and it may have resulted in potential bias in overestimation or underestimation. Wearable instruments, such as sports bracelets, can help assess the measure of sports activities in a more objective manner in future studies.

\section{Conclusions}

The association of adopting a healthy lifestyle and improvement in QoL is an important issue in the long-term management of cancer survivors. The present findings among Chinese women after their breast cancer diagnosis provide another important piece of evidence on the beneficial effect of regular participation in sports activities on QoL. Hence, health promotion programs after a breast cancer diagnosis should aim to encourage regular participation in sports activities. In addition, continual follow-up of the studied cohort will provide information on the potential benefit of engagement in regular sports activities on the outcomes of breast cancer.

Supplementary Materials: The following are available online at https:/ /www.mdpi.com/article/10 .3390 / cancers13236056/s1, Table S1: Modified Chinese Baecke Questionnaire.

Author Contributions: Conceptualization, Y.-Y.L. and W.Y.; methodology, S.C.H.; software, F.K.F.M.; validation, K.-L.C., V.A.Y. and R.L.; formal analysis, Y.-Y.L. and F.K.F.M.; investigation, S.C.H.; resources, S.C.H.; data curation, A.C. and C.K.; writing-original draft preparation, Y.-Y.L.; writingreview and editing, Y.-Y.L., S.C.H. and W.Y.; funding acquisition, S.C.H. and W.Y. All authors have read and agreed to the published version of the manuscript.

Funding: This research was funded by the World Cancer Research Fund International (grant number WCRF 2010/249 and WCRF 2014/1197) and The Madam Diana Hon Fun Kong Donation for Cancer Research (grant number CUHK Project Code 7104870).

Institutional Review Board Statement: The study was conducted according to the guidelines of the Declaration of Helsinki and approved by the Institutional Review Board of the Joint CUHKNTEC Clinical Research Ethics Committee and the KWC Research Ethics Committee of the Chinese University of Hong Kong and the Hong Kong Hospital Authority.

Informed Consent Statement: Informed consent was obtained from all subjects involved in the study. Written informed consent has been obtained from the patients to publish this paper.

Data Availability Statement: Data sharing is not applicable to this article.

Conflicts of Interest: The authors declare no conflict of interest.

\section{References}

1. Wong, I.O.; Schooling, C.M.; Cowling, B.J.; Leung, G.M. Breast cancer incidence and mortality in a transitioning Chinese population: Current and future trends. Br. J. Cancer 2015, 112, 167-170. [CrossRef] 
2. $\quad$ Rock, C.L.; Doyle, C.; Demark-Wahnefried, W.; Meyerhardt, J.; Courneya, K.S.; Schwartz, A.L.; Bandera, E.V.; Hamilton, K.K.; Grant, B.; McCullough, M.; et al. Nutrition and physical activity guidelines for cancer survivors. CA Cancer J. Clin. 2012, 62, 243-274. [CrossRef]

3. Perry, S.; Kowalski, T.L.; Chang, C.H. Quality of life assessment in women with breast cancer: Benefits, acceptability and utilization. Health Qual. Life Outcomes 2007, 5, 24. [CrossRef]

4. Montazeri, A. Quality of Life in Breast Cancer Patients: An Overview of the Literature. In Handbook of Disease Burdens and Quality of Life Measures; Preedy, V.R., Watson, R.R., Eds.; Springer: New York, NY, USA, 2010; pp. 2829-2855. [CrossRef]

5. Lee, E.S.; Lee, M.K.; Kim, S.H.; Ro, J.S.; Kang, H.S.; Kim, S.W.; Lee, K.S.; Yun, Y.H. Health-related quality of life in survivors with breast cancer 1 year after diagnosis compared with the general population: A prospective cohort study. Ann. Surg. 2011, 253, 101-108. [CrossRef] [PubMed]

6. Doege, D.; Thong, M.S.; Koch-Gallenkamp, L.; Bertram, H.; Eberle, A.; Holleczek, B.; Pritzkuleit, R.; Waldeyer-Sauerland, M.; Waldmann, A.; Zeissig, S.R.; et al. Health-related quality of life in long-term disease-free breast cancer survivors versus female population controls in Germany. Breast Cancer Res. Treat. 2019, 175, 499-510. [CrossRef] [PubMed]

7. Ibrahim, E.M.; Al-Homaidh, A. Physical activity and survival after breast cancer diagnosis: Meta-analysis of published studies. Med. Oncol. 2011, 28, 753-765. [CrossRef]

8. $\quad$ Beasley, J.M.; Kwan, M.L.; Chen, W.Y.; Weltzien, E.K.; Kroenke, C.H.; Lu, W.; Nechuta, S.J.; Cadmus-Bertram, L.; Patterson, R.E.; Sternfeld, B.; et al. Meeting the physical activity guidelines and survival after breast cancer: Findings from the after breast cancer pooling project. Breast Cancer Res. Treat. 2012, 131, 637-643. [CrossRef] [PubMed]

9. Schmid, D.; Leitzmann, M.F. Association between physical activity and mortality among breast cancer and colorectal cancer survivors: A systematic review and meta-analysis. Ann. Oncol. 2014, 25, 1293-1311. [CrossRef] [PubMed]

10. Basha, M.A.; Aboelnour, N.H.; Alsharidah, A.S.; Kamel, F.H. Effect of exercise mode on physical function and quality of life in breast cancer-related lymphedema: A randomized trial. Support. Care Cancer Off. J. Multinatl. Assoc. Support. Care Cancer 2021. Online ahead of print. [CrossRef]

11. Coletta, A.M.; Playdon, M.C.; Baron, K.G.; Wei, M.; Kelley, K.; Vaklavas, C.; Beck, A.; Buys, S.S.; Chipman, J.; Ulrich, C.M.; et al. The association between time-of-day of habitual exercise training and changes in relevant cancer health outcomes among cancer survivors. PLoS ONE 2021, 16, e0258135. [CrossRef] [PubMed]

12. Smith-Turchyn, J.; McCowan, M.E.; O’Loughlin, E.; Fong, A.J.; McDonough, M.H.; Santa Mina, D.; Arbour-Nicitopoulos, K.P.; Trinh, L.; Jones, J.M.; Bender, J.L.; et al. Connecting breast cancer survivors for exercise: Protocol for a two-arm randomized controlled trial. BMC Sports Sci. Med. Rehabil. 2021, 13, 128. [CrossRef] [PubMed]

13. Tami-Maury, I.M.; Liao, Y.; Rangel, M.L.; Gatus, L.A.; Shinn, E.H.; Alexander, A.; Basen-Engquist, K. Active Living After Cancer: Adaptation and evaluation of a community-based physical activity program for minority and medically underserved breast cancer survivors. Cancer 2021. Online ahead of print. [CrossRef]

14. Lahart, I.M.; Metsios, G.S.; Nevill, A.M.; Carmichael, A.R. Physical activity for women with breast cancer after adjuvant therapy. Cochrane Database Syst. Rev. 2018, 1, Cd011292. [CrossRef] [PubMed]

15. Covington, K.R.; Hidde, M.C.; Pergolotti, M.; Leach, H.J. Community-based exercise programs for cancer survivors: A scoping review of practice-based evidence. Support. Care Cancer Off. J. Multinatl. Assoc. Support. Care Cancer 2019, 27, 4435-4450. [CrossRef] [PubMed]

16. Zhang, X.; Li, Y.; Liu, D. Effects of exercise on the quality of life in breast cancer patients: A systematic review of randomized controlled trials. Support. Care Cancer Off. J. Multinatl. Assoc. Support. Care Cancer 2019, 27, 9-21. [CrossRef]

17. Campbell, K.L.; Winters-Stone, K.M.; Wiskemann, J.; May, A.M.; Schwartz, A.L.; Courneya, K.S.; Zucker, D.S.; Matthews, C.E.; Ligibel, J.A.; Gerber, L.H.; et al. Exercise Guidelines for Cancer Survivors: Consensus Statement from International Multidisciplinary Roundtable. Med. Sci. Sports Exerc. 2019, 51, 2375-2390. [CrossRef]

18. Blanchard, C.M.; Stein, K.D.; Baker, F.; Dent, M.F.; Denniston, M.M.; Courneya, K.S.; Nehl, E. Association between current lifestyle behaviors and health-related quality of life in breast, colorectal, and prostate cancer survivors. Psychol. Health 2004, 19, 1-13. [CrossRef]

19. Blanchard, C.M.; Courneya, K.S.; Stein, K. Cancer survivors' adherence to lifestyle behavior recommendations and associations with health-related quality of life: Results from the American Cancer Society's SCS-II. J. Clin. Oncol. Off. J. Am. Soc. Clin. Oncol. 2008, 26, 2198-2204. [CrossRef]

20. Chen, X.; Zheng, Y.; Zheng, W.; Gu, K.; Chen, Z.; Lu, W.; Shu, X.O. The effect of regular exercise on quality of life among breast cancer survivors. Am. J. Epidemiol. 2009, 170, 854-862. [CrossRef]

21. Smith, A.W.; Alfano, C.M.; Reeve, B.B.; Irwin, M.L.; Bernstein, L.; Baumgartner, K.; Bowen, D.; McTiernan, A.; Ballard-Barbash, R. Race/ethnicity, physical activity, and quality of life in breast cancer survivors. Cancer Epidemiol. Biomark. Prev. Publ. Am. Assoc. Cancer Res. Cospons. Am. Soc. Prev. Oncol. 2009, 18, 656-663. [CrossRef]

22. Blanchard, C.M.; Stein, K.; Courneya, K.S. Body mass index, physical activity, and health-related quality of life in cancer survivors. Med. Sci. Sports Exerc. 2010, 42, 665-671. [CrossRef] [PubMed]

23. Voskuil, D.W.; van Nes, J.G.; Junggeburt, J.M.; van de Velde, C.J.; van Leeuwen, F.E.; de Haes, J.C. Maintenance of physical activity and body weight in relation to subsequent quality of life in postmenopausal breast cancer patients. Ann. Oncol. 2010, 21, 2094-2101. [CrossRef] 
24. Paxton, R.J.; Phillips, K.L.; Jones, L.A.; Chang, S.; Taylor, W.C.; Courneya, K.S.; Pierce, J.P. Associations among physical activity, body mass index, and health-related quality of life by race/ethnicity in a diverse sample of breast cancer survivors. Cancer 2012, 118, 4024-4031. [CrossRef]

25. Gong, X.H.; Wang, J.W.; Li, J.; Chen, X.F.; Sun, L.; Yuan, Z.P.; Yu, J.M. Physical exercise, vegetable and fruit intake and healthrelated quality of life in Chinese breast cancer survivors: A cross-sectional study. Qual. Life Res. Int. J. Qual. Life Asp. Treat. Care Rehabil. 2017, 26, 1541-1550. [CrossRef]

26. Shin, W.K.; Song, S.; Jung, S.Y.; Lee, E.; Kim, Z.; Moon, H.G.; Noh, D.Y.; Lee, J.E. The association between physical activity and health-related quality of life among breast cancer survivors. Health Qual. Life Outcomes 2017, 15, 132. [CrossRef]

27. Hart, V.; Trentham-Dietz, A.; Berkman, A.; Fujii, M.; Veal, C.; Hampton, J.; Gangnon, R.E.; Newcomb, P.A.; Gilchrist, S.C.; Sprague, B.L. The association between post-diagnosis health behaviors and long-term quality of life in survivors of ductal carcinoma in situ: A population-based longitudinal cohort study. Qual. Life Res. Int. J. Qual. Life Asp. Treat. Care Rehabil. 2018, 27, 1237-1247. [CrossRef] [PubMed]

28. Ahn, S.J.; Kim, J.H.; Chun, M.; Yoon, W.S.; Rim, C.H.; Yang, D.S.; Lee, J.H.; Kim, K.; Kong, M.; Kim, S.; et al. Physical activity status in relation to quality of life and dietary habits in breast cancer survivors: Subset analyses of KROG 14-09 nationwide questionnaire study. Qual. Life Res. Int. J. Qual. Life Asp. Treat. Care Rehabil. 2020, 29, 3353-3361. [CrossRef]

29. Park, J.H.; Lee, D.H.; Kim, S.I.; Kim, N.K.; Jeon, J.Y. Moderate to vigorous physical activity participation associated with better quality of life among breast and colorectal cancer survivors in Korea. BMC Cancer 2020, 20, 365. [CrossRef] [PubMed]

30. Montagnese, C.; Porciello, G.; Vitale, S.; Palumbo, E.; Crispo, A.; Grimaldi, M.; Calabrese, I.; Pica, R.; Prete, M.; Falzone, L.; et al. Quality of Life in Women Diagnosed with Breast Cancer after a 12-Month Treatment of Lifestyle Modifications. Nutrients 2020, 13, 136. [CrossRef]

31. Chen, M.J.; Wu, W.Y.Y.; Yen, A.M.F.; Fann, J.C.Y.; Chen, S.L.S.; Chiu, S.Y.H.; Chen, H.H.; Chiou, S.T. Body mass index and breast cancer: Analysis of a nation-wide population-based prospective cohort study on 1393985 Taiwanese women. Int. J. Obes. 2016, 40, 524-530. [CrossRef]

32. Lei, Y.-Y.; Ho, S.C.; Kwok, C.; Cheng, A.; Cheung, K.L.; Lee, R.; Mo, F.; Yeo, W. Weight and waist-to-hip ratio change pattern during the first five years of survival: Data from a longitudinal observational Chinese breast cancer cohort. BMC Cancer 2021, 21, 839. [CrossRef]

33. Lei, Y.Y.; Ho, S.C.; Cheng, A.; Kwok, C.; Cheung, K.L.; He, Y.Q.; Lee, C.I.; Lee, R.; Yeo, W. Dietary changes in the first 3 years after breast cancer diagnosis: A prospective Chinese breast cancer cohort study. Cancer Manag. Res. 2018, 10, 4073-4084. [CrossRef]

34. Lei, Y.Y.; Ho, S.C.; Cheng, A.; Kwok, C.; Lee, C.I.; Cheung, K.L.; Lee, R.; Loong, H.H.F.; He, Y.Q.; Yeo, W. Adherence to the World Cancer Research Fund/American Institute for Cancer Research Guideline Is Associated with Better Health-Related Quality of Life Among Chinese Patients with Breast Cancer. J. Natl. Compr. Cancer Netw. JNCCN 2018, 16, 275-285. [CrossRef]

35. Lei, Y.-Y.; Ho, S.C.; Kwok, C.; Cheng, A.; Cheung, K.L.; Lee, R.; Yeo, W. Longitudinal changes in sports activity from pre-diagnosis to first five years post-diagnosis: A prospective Chinese breast cancer cohort study. BMC Cancer 2020, 20, 1013. [CrossRef]

36. Lei, Y.Y.; Ho, S.C.; Cheng, A.; Kwok, C.; Cheung, K.L.; He, Y.Q.; Lee, R.; Yeo, W. The association between soy isoflavone intake and menopausal symptoms after breast cancer diagnosis: A prospective longitudinal cohort study on Chinese breast cancer patients. Breast Cancer Res. Treat. 2020, 181, 167-180. [CrossRef] [PubMed]

37. Lei, Y.Y.; Ho, S.C.; Lau, T.K.H.; Kwok, C.; Cheng, A.; Cheung, K.L.; Lee, R.; Yeo, W. Longitudinal change of quality of life in the first five years of survival among disease-free Chinese breast cancer survivors. Qual. Life Res. Int. J. Qual. Life Asp. Treat. Care Rehabil. 2021, 30, 1583-1594. [CrossRef] [PubMed]

38. Edge, S.B.; Byrd, D.R.; Compton, C.C.; Fritz, A.G.; Greene, F.L.; Trotti, A. (Eds.) AJCC Cancer Staging Manual, 7th ed.; Springer: New York, NY, USA, 2010.

39. WHO/IASO/IOTF. The Asia-Pacific Perspective: Redefining Obesity and Its Treatment; Health Communications Australia: Melbourne, Australia, 2000.

40. Ho, S.C.; Yu, R.; Chan, S. Comparison of the modified Chinese Baecke Questionnaire with a 3-day activity diary in a Hong Kong Chinese population. Asia-Pac. J. Public Health 2015, 27, Np2358-Np2371. [CrossRef]

41. Ainsworth, B.E.; Haskell, W.L.; Herrmann, S.D.; Meckes, N.; Bassett, D.R., Jr.; Tudor-Locke, C.; Greer, J.L.; Vezina, J.; Whitt-Glover, M.C.; Leon, A.S. 2011 Compendium of Physical Activities: A second update of codes and MET values. Med. Sci. Sports Exerc. 2011, 43, 1575-1581. [CrossRef] [PubMed]

42. World Cancer Research Fund/American Institute for Cancer Research. Diet, Nutrition, Physical Activity and Cancer: A Global Perspective. Continuous Update Project Expert Report 2018. Available online: https:/ /www.wcrf.org/diet-and-cancer/ (accessed on 11 November 2021).

43. Chie, W.C.; Chang, K.J.; Huang, C.S.; Kuo, W.H. Quality of life of breast cancer patients in Taiwan: Validation of the Taiwan Chinese version of the EORTC QLQ-C30 and EORTC QLQ-BR23. Psychooncology 2003, 12, 729-735. [CrossRef]

44. Aaronson, N.K.; Ahmedzai, S.; Bergman, B.; Bullinger, M.; Cull, A.; Duez, N.J.; Filiberti, A.; Flechtner, H.; Fleishman, S.B.; de Haes, J.C.; et al. The European Organization for Research and Treatment of Cancer QLQ-C30: A quality-of-life instrument for use in international clinical trials in oncology. J. Natl. Cancer Inst. 1993, 85, 365-376. [CrossRef]

45. Fayers, P.M.; Aaronson, N.K.; Bjordal, K.; Groenvold, M.; Curran, D.; Bottomley, A.; on behalf of the EORTC Quality of Life Group. The EORTC QLQ-C30 Scoring Manual, 3rd ed.; European Organisation for Research and Treatment of Cancer: Brussel, Belgium, 2001. 
46. Raboud, J.M.; Singer, J.; Thorne, A.; Schechter, M.T.; Shafran, S.D. Estimating the effect of treatment on quality of life in the presence of missing data due to drop-out and death. Qual. Life Res. Int. J. Qual. Life Asp. Treat. Care Rehabil. 1998, 7, 487-494. [CrossRef] [PubMed]

47. US Department of Health and Human Services. 2008 Physical Activity Guidelines for Americans. Available online: http: //www.health.gov /PAGuidelines/guidelines/ (accessed on 11 May 2021).

48. Courneya, K.S.; Mackey, J.R.; Bell, G.J.; Jones, L.W.; Field, C.J.; Fairey, A.S. Randomized controlled trial of exercise training in postmenopausal breast cancer survivors: Cardiopulmonary and quality of life outcomes. J. Clin. Oncol. Off. J. Am. Soc. Clin. Oncol. 2003, 21, 1660-1668. [CrossRef]

49. Wiggins, M.S.; Simonavice, E.M. Cancer prevention, aerobic capacity, and physical functioning in survivors related to physical activity: A recent review. Cancer Manag. Res. 2010, 2, 157-164. [CrossRef]

50. Phillips, S.M.; McAuley, E. Physical activity and quality of life in breast cancer survivors: The role of self-efficacy and health status. Psychooncology 2014, 23, 27-34. [CrossRef]

51. Holick, C.N.; Newcomb, P.A.; Trentham-Dietz, A.; Titus-Ernstoff, L.; Bersch, A.J.; Stampfer, M.J.; Baron, J.A.; Egan, K.M.; Willett, W.C. Physical activity and survival after diagnosis of invasive breast cancer. Cancer Epidemiol. Biomark. Prev. Publ. Am. Assoc. Cancer Res. Cospons. Am. Soc. Prev. Oncol. 2008, 17, 379-386. [CrossRef] [PubMed]

52. Irwin, M.L.; Smith, A.W.; McTiernan, A.; Ballard-Barbash, R.; Cronin, K.; Gilliland, F.D.; Baumgartner, R.N.; Baumgartner, K.B.; Bernstein, L. Influence of pre- and postdiagnosis physical activity on mortality in breast cancer survivors: The health, eating, activity, and lifestyle study. J. Clin. Oncol. Off. J. Am. Soc. Clin. Oncol. 2008, 26, 3958-3964. [CrossRef] [PubMed]

53. Sternfeld, B.; Weltzien, E.; Quesenberry, C.P., Jr.; Castillo, A.L.; Kwan, M.; Slattery, M.L.; Caan, B.J. Physical activity and risk of recurrence and mortality in breast cancer survivors: Findings from the LACE study. Cancer Epidemiol. Biomark. Prev. Publ. Am. Assoc. Cancer Res. Cospons. Am. Soc. Prev. Oncol. 2009, 18, 87-95. [CrossRef]

54. Bertram, L.A.; Stefanick, M.L.; Saquib, N.; Natarajan, L.; Patterson, R.E.; Bardwell, W.; Flatt, S.W.; Newman, V.A.; Rock, C.L.; Thomson, C.A.; et al. Physical activity, additional breast cancer events, and mortality among early-stage breast cancer survivors: Findings from the WHEL Study. Cancer Causes Control CCC 2011, 22, 427-435. [CrossRef]

55. Chen, X.; Lu, W.; Zheng, W.; Gu, K.; Matthews, C.E.; Chen, Z.; Zheng, Y.; Shu, X.O. Exercise after diagnosis of breast cancer in association with survival. Cancer Prev. Res. 2011, 4, 1409-1418. [CrossRef]

56. Irwin, M.L.; McTiernan, A.; Manson, J.E.; Thomson, C.A.; Sternfeld, B.; Stefanick, M.L.; Wactawski-Wende, J.; Craft, L.; Lane, D.; Martin, L.W.; et al. Physical activity and survival in postmenopausal women with breast cancer: Results from the women's health initiative. Cancer Prev. Res. 2011, 4, 522-529. [CrossRef]

57. Holmes, M.D.; Chen, W.Y.; Feskanich, D.; Kroenke, C.H.; Colditz, G.A. Physical activity and survival after breast cancer diagnosis. JAMA 2005, 293, 2479-2486. [CrossRef] [PubMed]

58. McTiernan, A. Mechanisms linking physical activity with cancer. Nat. Rev. Cancer 2008, 8, 205-211. [CrossRef] [PubMed]

59. Ballard-Barbash, R.; Friedenreich, C.M.; Courneya, K.S.; Siddiqi, S.M.; McTiernan, A.; Alfano, C.M. Physical activity, biomarkers, and disease outcomes in cancer survivors: A systematic review. J. Natl. Cancer Inst. 2012, 104, 815-840. [CrossRef] [PubMed]

60. McDermott, L.A.; Murphy, M.H.; McNeilly, A.M.; Rankin, J.P.; Gracey, J.H. Biological markers as an outcome measure of exercise in cancer rehabilitation: A systematic review. J. Cancer Res. Ther. 2018, 14, 267-277. [CrossRef] [PubMed] 